Vol. 4, No. 1, 2018

\title{
FORMATION OF EUROPEAN INTEGRATION DEVELOPMENT STRATEGY OF UKRAINE
}

\author{
Yevhen Podorozhnii ${ }^{1}$ \\ Kharkiv National University of Internal Affairs, Ukraine \\ Sandra Boldizhar ${ }^{2}$, Olexandr Sofilkanich ${ }^{3}$ \\ Uzhhorod National University, Ukraine
}

\begin{abstract}
Today European integration is a strategic course of Ukraine, its speed increases. It obliges to pay attention to the consequences of European integration. European integration, that is, formation and further strengthening of ties with European countries, has a complex nature (economic, political, social, cultural, etc.) at all levels transnational, interregional, between separate economic entities. The relevance of the article's topic is determined by objective nature of European integration process in Ukrainian economy and complex nature of consequences of this process. The purpose of the article is the analysis of the influence of European integration process on the economic development of the country on the basis of scenario approach. The presence of essential regional imbalances in the socio-economic development in Ukraine requires differentiated approaches to the elaboration of development measures aimed at promoting the creation of free trade area, as well as strengthening economic and sectoral cooperation between Ukraine and the EU. Thus, there appears a necessity to monitor and evaluate progress of economic reforms in regions of Ukraine in the context of European integration processes in order to reveal strengths and weaknesses, to substantiate priorities and means of their achievement, as well as possibility of their timely adjustment for improving the region's ability to follow the vector of European integration. For the purpose implementation, it seems most appropriate to calculate an integral value - European Integration Index $\left(I_{p}\right)$. In the most general terms, the index is a relative magnitude, designed to fulfil the role of a generalized measure of a certain phenomenon, which is formed under the influence of heterogeneous components, which cannot be directly summed up. European integration consequences for the economy of Ukraine are considered and it is shown that these consequences can have not only a positive nature in the form of new opportunities and open markets but also pose a threat. Scenarios for changing the national economy of Ukraine as a result of the influence of European integration processes are determined. A description for each of these scenarios is provided. Assessment of such scenarios is done according to criteria of desirability, probability, and time of realization. A relation between the considered scenarios for changing the national economy of Ukraine over the influence of European integration processes taking into account probabilistic cause-and-effect relationships between individual scenarios is shown. Consequences of these scenarios for the economic development of Ukraine are presented. The research result is the detection and characteristic of scenarios of changes in the economy of Ukraine as a result of the influence of European integration processes, as well as the characteristic of the influence of such scenarios on the country's economic development. Scientific novelty of research results is defining scenarios of changes in Ukrainian economy under the influence of European integration processes, characteristics of these scenarios and relations among them taking into account the influence of such scenarios on the country's economic security. The practical value of research results is considered a possibility to provide adaptation of regions of Ukraine to the consequences of European integration processes in the economic and legal field.
\end{abstract}

Key words: European integration, economic development, national security, infrastructure, planning policy, regional economic activity.

JEL Classification: E01, H56, O18, O21, R11

\footnotetext{
Corresponding author:

${ }^{1}$ Department of Labour and Commercial Law, Kharkiv National University of Internal Affairs.

E-mail: podorozniy@ukr.net

${ }^{2}$ Department of Administrative, Financial, and Information Law, Uzhhorod National University.

E-mail: boldizarso.gmail.com

${ }^{3}$ Department of Criminal Law and Procedure, Uzhhorod National University.

E-mail:sov@ukr.net
} 


\section{Introduction}

One of the objective trends in the modern economy of Ukraine is European integration, i.e. formation and further strengthening of relations with countries of the EU at all levels - interstate, interregional, among separate economic entities. Today European integration is a strategic course of Ukraine, its speed increases. It obliges to pay attention to the challenges and threats of European integration for the formation of a modern strategy of European integration development of Ukraine.

Relevant is the issue of the establishment of friendly, partnership relations between the EU and Ukraine. European Union is an active participant in the modern geopolitical space. European unification is one of the most significant geopolitical events of the XX century. As a result of a large-scale and deep integration, European Union has become a powerful geopolitical centre. The main task of Ukraine is to return to European civilizational space. Specific geopolitical location and history of long-term cooperation with European countries determine the interest of Ukraine in an active participation towards European integration processes.

Activation of European integration processes means a more intensive inclusion of Ukraine in the international cooperation in relation to conflict resolution and counteraction to the latest threats to international security.

The purpose of the research is the analysis of the current state of development of European integration processes and formation of adaptive directions from a strategic perspective.

The main objectives are the formation of such a strategic scenario that would allow: conducting an adequate analysis of the current state of Ukrainian development; creating opportunities for regular monitoring of the state and directions of Ukraine's movement in a specific vector; and the main one, proposing modern directions for the integration of Ukraine into European space.

\section{The methodology of research}

Full involvement of Ukraine in the European communityinvolves creating and maintaining conditions for strengthening economic and trade relations, which will facilitate the gradual integration of the national economy into the European market. The presence of essential regional imbalances in the socio-economic development in Ukraine requires differentiated approaches to the elaboration of measures of regional development designed to facilitate the creation of free trade area, as well as strengthen economic and sectoral cooperation between Ukraine and the EU (Ivankiv, 2015; European integration, 2011). Thus, there appears a necessity to monitor and evaluate progress of economic reforms in regions of Ukraine, to substantiate priorities and means of their achievement, as well as possibilities of their timely adjustment for improving the ability to follow the vector of European integration (Avanasova, 2016; Hluschenko, Tuleninova, 2016).

Given the civilizational choice of Ukraine and confession of European democratic values, in June 1998, the President approved by his decree the strategy of Ukraine's integration into the European Union. On its basis, practical, purposeful, and consecutive steps on the realization of the goal of gaining full membership in the European Union were developed. So, the Message of the President of Ukraine to the Verkhovna Rada "European Choice. Conceptual Bases of the Strategy of Economic and Social Development of Ukraine for 2002-2011" outlines the plan of concrete actions of the authorities. In addition to the tasks for creating the preconditions for joining the EU, the task of bringing the legislation of Ukraine in line with the EU legal requirements in priority areas is also distinguished.

However, Ukraine has not fulfilled a number of commitments to the Council of Europe. Today there is a need to prepare and adopt several hundreds of laws. Most of the draft bills were prepared and submitted to the Verkhovna Rada in the prescribed manner several years ago but, for various purposes, they are waiting for consideration for a long time. Bills aimed at the realization of social, cultural, and other rights and freedoms of man and citizen are considered as the priority ones.

Given the conceptual approach, adaptation of Ukrainian legislation to the legislation of the $\mathrm{EU}$ is to converge with the modern European system of law, which will ensure the development of the political, entrepreneurial, social, cultural activity of citizens of our state, its economic development within the framework of the EU, and will contribute to the gradual growth of the welfare of citizens, bringing it to a level that has developed in the EU member states. Adaptation of the legislation of Ukraine envisages reformation of its legal system and gradual alignment with European standards and covers private, customs, labour, financial legislation, laws on intellectual property, labour protection, life and health protection, environment, consumer protection, technical rules and standards, transport, as well as other sectors identified in the Partnership and Cooperation Agreement.

While considering prospects of the introduction of ideas of sustainable development in the consciousness of Ukrainian citizens, it should be recognized that for a long time, being in a transitive state, our society needs more regulatory concretization of measures on harmonization of relations with the EU and within the country.

Modern science proposes a wide toolkit for determining the state and dynamics of processes taking place in various spheres of society. However, now there are no studies related to measuring progressive changes in the economic sphere in terms of achieving the main 
objectives of the Association Agreement between Ukraine and the European Union (Avanasova, 2016). Given the special relevance of the issue associated with the fulfilment of the basic provisions of the Association Agreement between Ukraine and the EU (The Association Agenda, 16.03.2015) and the Association Agenda (Association Agreement, 27.06.2014), it becomes necessary to develop a methodology that allows quantifying progress in the implementation of relevant economic reforms in regions of Ukraine (The EU-Ukraine Association Agenda on 16.03.2015).

For the research realization, the most expedient seems the calculation of the integral index of European integration progress (Ip). In the most general terms, the index is a relative magnitude, designed to fulfil the role of a generalized measure of a certain phenomenon, which is formed under the influence of heterogeneous components, which cannot be directly summed up. Then Ip can be defined as a relative integrated magnitude that is calculated on the basis of aggregation of individual indicators that reflect the effectiveness of achieving the main objectives of economic integration with the EU in the regional dimension (Derij, Zosymenko, 2016).

Given the foregoing, one should dwell on the way of calculating Ip, which:

- allows going to scale with a range from -1 to 1 or from 0 to 1 as it limits the maximum level of European integration development of the region for a certain period, which allows using it as a benchmark for determining the position of one region compared to other regions of Ukraine. The calculation by the geometric mean method is impossible if the values of normalized partial coefficients will fluctuate in the interval $[-1 ; 1]$;
- provides a possibility of the use weighing coefficients that reflect the extent, to which each component is affected, reflecting the effectiveness of achieving the main objectives of economic integration with the EU in a regional dimension;

- allows calculating Ip even in the case of acquiring zero value by one of its component indicators. Given all the above, we consider the most appropriate to use the weighted arithmetic mean for the calculation of the European Integration Index (Korobov, 2016; Pryimak, 2009)

In order to determine directions of the formation of development strategy, to calculate Ip, it is necessary to choose indicators, which, according to the EU-Ukraine Association Agreement, can be combined into two main directions:

I. Trade and trade-related issues;

II. Economic and sectoral cooperation.

Each of them will include the corresponding package of indicators, which reflect the priority directions of reforms (Figure 1).

For their description, it is necessary to select public statistical indicators, information about which is in open access:

1.1. Trade in commodities. As one of the conditions for the functioning of the free trade zone between Ukraine and the EU is to ensure the free access of Ukrainianorigin goods to the countries of the European Union and vice versa, indicators were selected as quantitative indicators of this process:

- the share of export of goods to the EU countries in total, \%;

- the share of import of goods from the EU countries in total, \%.

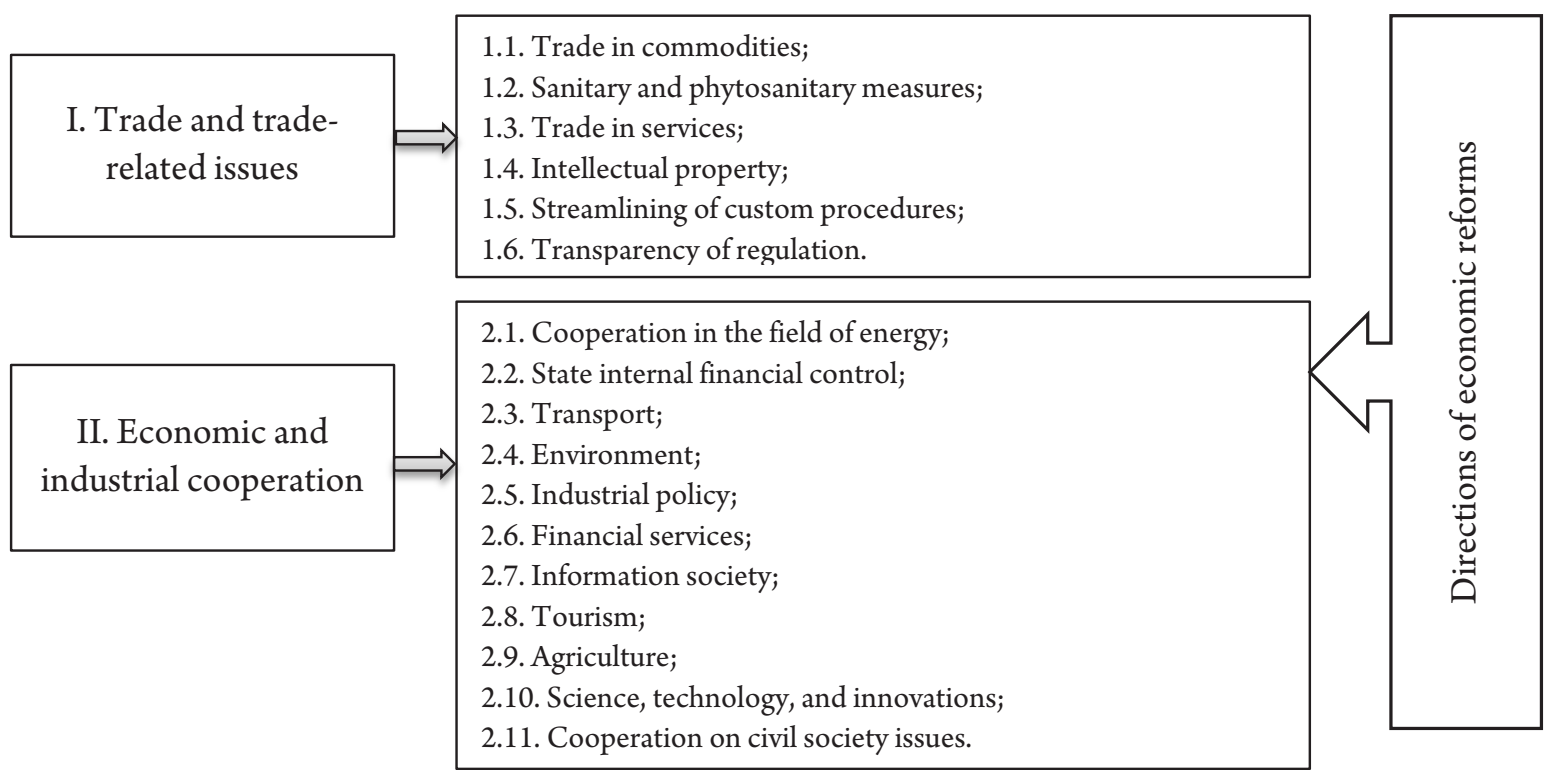

Fig. 1. Directions of economic development determined by the Association Agreement between Ukraine and the EU (formed by the author based on: Korobov, 2016; Pogorelov, Adamenko, 2015; Koriavets, 2017) 
1.2. Sanitary and phytosanitary measures. To the indicators that indirectly display economic results of approximation of Ukrainian legislation in the field of sanitary and phytosanitary measures to the EU legislation, we included indicators reflecting the number of objects, which are granted by the State Food and Veterinary Service with the right to export food products (dairy products, meat products, eggs and egg products, honey and beekeeping products, mayonnaise, mayonnaise sauces, and margarine) to the EU countries.

1.3. Trade in services and investments. An important direction of the state policy in the area of business establishment, trade in services, and e-commerce should be, in particular, simplification of the creation and operation of companies, branches, and representative establishments, protection of investors' rights due to further approximation of the legislation in these areas to the legislation, standards, and practices of the EU.

The main indices of the growth of such indicators, such as: the share of exports of services to EU countries, $\%$; the share of imports from EU countries, \%; the share of direct investments of non-residents from the EU in the region in the total volume, $\%$.

1.4. Intellectual property. One of the priority vectors of reforms in Ukraine in terms of European integration is the improvement of the national legislation taking into account the best world practice. The result of this should be the transformation of intellectual property into a strategic resourcein the system offorming nationalwealth and improving the competitiveness of the economy of Ukraine, acceleration of innovative development and integration of Ukraine into international economic space. Accordingly, to resulting statistical indicators that reflect the efficiency of mechanisms of obtaining legal protection in the field of intellectual property, the creation of favourable investment climate, we propose to include the following: the number of applications for inventions; the number of applications for utility models from national applicants.

1.5. Streamlining of customs procedures and promotion of trade. Since the reformation of customs sphere is carried out on the basis of a new edition of the Customs Code of Ukraine, which is developed taking into account provisions of the International Convention on the Simplification and Harmonization of Customs Procedures, the Convention on Temporary Admission, the Union Customs Code, the only factor that can influence customs procedures is human one. It is possible to indirectly reflect such a negative influence at the regional level with the help of analysis of indicators of the number of appeals of individuals and legal entities in the light of zones of customs activities. Another important goal in the context of European integration of Ukraine is to reduce the number of points of coincidence of business and state, which is advisable to show by using an indicator of the number of inspections of business entities by the Tax and Customs
Audit Department relative to the number of economic entities.

1.6. Transparency of regulation. An indicator that, in our view, reflects the transparency of regulation is the number of suspended violations in the form of anticompetitive actions of authorities in the regional context.

2.1. Cooperation in the field of energy. Taking into consideration that the main purpose of cooperation of Ukraine and the EU countries is to improve energy security, competitiveness, and stability, performance indicators by this package of reforms were selected as a statistical indicator - disincentive: losses of energetic material and petroleum refinery products in the process of distribution, transportation, percentage to total volume. On the other hand, cooperation in the field of energy is aimed at providing available energetic resources for consumers, thus the second indicator having a chilling effect on the Index was selected as a level of arrears for the payment of housing and communal services, $\%$.

2.2. State internal financial control. Cooperation in the field of public finance management is directed to providing development of fiscal policy and reliable systems of internal control and external audit, which are grounded on international standards, as well as meet the fundamental principles of accountability, transparency, economy, efficiency, and effectiveness. Thus, the main signs of progressiveness in this area should be a reduction of the following indicators: illegal and not for the intended purpose spent costs, shortage (theft) of funds and material values, thousand $\mathrm{UAH}$; the volume of foregone financial resources, thousand UAH.

2.3. Transport. So far as basic vectors of cooperation in the field of transport include, in particular, the implementation of efficient and safe transportation, as well as the strengthening of the main transport links between the territories of the parties, thus the list of indicators of this package of reforms includes the following statistical indicators: the share of exports of transport services to the total volume of exports of services to EU countries, \%; the share of import of transport services in the total volume of imports of services from the EU countries, \%.

The indicator of the number of traffic accidents on the roads and streets of the region in relation to the passenger traffic of the ground type of transport (units per million pass. $\mathrm{km}$ ) was chosen due to the importance of achieving the task of increasing the efficiency and safety of transportation.

2.4. Environment. Implementation of long-term objectives of sustainable development and green economy envisages the availability of proper investment provision of ecologization processes in regions of Ukraine. Thus indicator by this package is identified as an indicator of the share of capital investment in the protection and rational use of natural resources in the total volume, $\%$. 
2.5. Industrial policy. A priority direction of the cooperation of Ukraine and the EU in the industry and business is to improve conditions for entrepreneurial activity. Thus, positive achievements in this area should appear in the growth of such indicators as: the share of foreign direct investments in the industry in the total volume, \%; the share of exports of services for the processing of material resources in the total volume of exports of services, \%; the share of imports of services for the processing of material resources in the total volume of imports of services, \%; the share of exports of industrial products in total exports of goods to the EU countries, \%; the share of imports of industrial products in total imports of goods from the EU countries, \%.

2.6. Financial services. Given the importance of the development of the financial services sphere for the establishment of a full-fledged market economy to evaluate the effectiveness of reforms by this package, it is expedient to use the indicators:

- the share of exports of financial services in the total volume of exports of services, \%;

- the share of imports of financial services in the total volume of imports of services, \%;

- the share of enterprises providing financial services and insurance services in the total number of enterprises, $\%$.

2.7. Information society. Cooperation in this field covers, in particular, promoting broadband access, improving network security and widespread use of computer and information technologies by individuals, business, and administrative authorities due to the development of local Internet resources and the introduction of online services. Therefore, as statistical indicators, we have chosen indicators:

- the share of enterprises using computers in the total number of enterprises, $\%$;

- the share of employees who used computers among the total number of employees, $\%$;

- the share of enterprises having access to the Internet, in the total number of enterprises using computers, \%; - the share of enterprises having a website or homepage in the total number of enterprises having Internet access, \%;

- the share of enterprises that carried out automated data exchange in the total number of enterprises using computers, \%;

- the share of subscribers of the Internet in the total population, \%;

- the share of mobile communication subscribers in the total population, $\%$;

- RITS index of the level of IT penetration into the life of society.

2.8. Tourism. By this package, economic reforms should be aimed at the promotion and development of tourism products and markets, infrastructure, human resources, and institutional structures, building capacity in the tourism industry in order to improve the quality of provision of tourism services. In the structure of the indicators, which allow quantifying the effectiveness of reforms in the field of tourism, we include: the share of subjects of tourism activity in the total number of economic entities, \%; the number of tourists served by subjects of tourism activity; the share of exports of services connected with travel in the total volume of exports of services, \%; the share of imports of services related to travel in the total volume of imports of services, $\%$.

2.9. Agriculture. Reforms in this package are directed to the improvement of competitiveness of agriculture and efficiency and transparency of markets, as well as conditions for investing, sharing best practices on policy support mechanisms in the field of agriculture and rural development. Statistical indicators of the effectiveness of reforms are indicators:

- agricultural production per 1 person, UAH;

- labour productivity in agricultural enterprises per 1 employed, UAH;

- the level of profitability of agricultural production in agricultural enterprises, \%;

- the share of small and medium enterprises, as a percentage of the total number of agricultural enterprises;

- the share of foreign direct investment in agriculture in total, \%.

2.10. Science, technology, and innovations. Cooperation in this area should help Ukraine in the support of reformation and reorganization of the system of management of scientific sphere and research institutions (in particular, in the development of its potential as regards development of science and technology) for the purpose of promoting the development of the competitive economy and knowledge-based society. Taking this into consideration, we have selected such indicators of the effectiveness of reforms in terms of their impact on creating favourable conditions for the elaboration, development, and commercialization of innovations by business entities: - the share of organizations performing scientific and scientific-technical work in the total number of enterprises, \%;

- the share of industrial enterprises engaged in innovation activities, as a percentage of the total number of industrial enterprises;

- the share of financing of scientific and scientific and technical works at the expense of foreign countries, \%; - the quantity of introduced new technological processes at industrial enterprises;

- the quantity of mastered innovative types of products at industrial enterprises;

- the share of the realized innovative production of industry in the total volume of industrial products, $\%$

2.11. Cooperation on civil society issues. As far as reforms of this package are intended to promote the process of institutional building and consolidation of organizations of civil society, as a quantitative indicator 
of progressive changes, the indicator of the number of legalized civic organizations in relation to the population of the region was chosen.

Then in the general form, the formula for calculating the European Integration Index takes the form (1) (Pryimak, 2009; Korobov, 2016):

$$
I_{p}=\frac{N_{t} * w t+N_{e} * w e}{2}
$$

$I_{p}$ - the index of European integration economic progress of the region;

$\mathrm{N}_{\mathrm{t}}$ - an indicator characterizing the direction of reforming "trade and related areas";

$\mathrm{N}_{\mathrm{e}}$ - an indicator characterizing the direction of reforming "economic and sectoral cooperation";

$\mathrm{Wt}$, we - weighting coefficients, direction levers, which are appropriately formed by the expert evaluation method.

It is clear that integrated index can be calculated only in the case when the value of each of the primary indicators will be reduced to the same dimension. To do this, it is needed to normalize them. Among the methods of normalization, we selected the Min-Max method, which allows avoiding the distorting effect of extremely large values and reduces all data to one range within 0 and 1 . For the normalization of indicatorsstimulants, one should use formula (2), and for indicators-disincentives - formula (3).

$$
y_{i j}=\frac{x_{i j}-x_{i \min }}{x_{i \max }-x_{i \min }}
$$

$y_{i j}$ - dimensionless (normalized) value of the i-th statistical indicator in the $\mathrm{j}$-th region;

$x_{i j}$ - the value of the $i$-th statistical indicator in the $j$-th region;

$\mathrm{x}_{\min }$ and $\mathrm{x}_{\max }$ - the minimum and maximum values of the $\mathrm{i}$-th statistical indicator.

$$
y_{i j}=\frac{x_{i \min }-x_{i j}}{x_{i \max }-x_{i \min }}
$$

This method, although somewhat complicates the process of calculation in dynamics, at the same time, allows more adequately reflecting the amplitude of fluctuations of the corresponding quantities. In addition, the Min-Max method allows better data transfer in cases where the values of statistical data are close to each other by fields.

\section{Results and discussion}

As a result of conducted calculations and research, the European Integration Index for each region (EIIR) is obtained, which consists of two intermediate Indices for reform directions, which, in turn, consist of Indices for each individual reform package within the respective direction.
The research is conducted within the project "Visegrád Group Countries' Assistance in Assessing Economic Reforms in Regions of Ukraine in Terms of the EU Integration" that was carried out by the Polissya Foundation for International and Regional Studies (Chernihiv), the Association of Regional Analytical Centres with the support of the International Visegrád Fund (Slovakia), the Research Centre of the Slovak Foreign Policy Association (Slovakia), the International Centre for Democratic Transition ICDT (Hungary), Polish-Ukrainian Cooperation Foundation PAUCI (Poland), the Policy Association for an Open Society PASOS (Czech Republic), and Chernihiv National University of Technology (Koriavets, 2017; Honcharenko, Bohatyrenko, Bakal, Vynokurova, Halimuk, Hejderova, 2017).

Table 1

Analysis of dynamics of changes of the Index of European integration economic progress of the regions of Ukraine, 2014-2016

\begin{tabular}{|c|l|c|c|c|}
\hline \multicolumn{1}{|c|}{ Region } & $\begin{array}{c}\text { Rating for } \\
2016\end{array}$ & $\begin{array}{c}\text { Rating for } \\
2015\end{array}$ & $\begin{array}{c}\text { Rating for } \\
2014\end{array}$ \\
\hline 1 & Chernivtsi & 0,4960 & 0,4309 & 0,4151 \\
\hline 2 & Volyn & 0,4760 & 0,4370 & 0,3021 \\
\hline 3 & Ternopil & 0,4649 & 0,4262 & 0,3937 \\
\hline 4 & Lviv & 0,4518 & 0,4982 & 0,4828 \\
\hline 5 & Ivano-Frankivsk & 0,4369 & 0,4081 & 0,4021 \\
\hline 6 & Transcarpathian & 0,4341 & 0,4699 & 0,4144 \\
\hline 7 & Chernihiv & 0,3983 & 0,3115 & 0,2851 \\
\hline 8 & Rivne & 0,3952 & 0,3359 & 0,2332 \\
\hline 9 & Sumy & 0,3932 & 0,4136 & 0,2674 \\
\hline 10 & Kyiv & 0,3684 & 0,3727 & 0,3288 \\
\hline 11 & Zhytomyr & 0,3604 & 0,3908 & 0,2616 \\
\hline 12 & Kherson & 0,3546 & 0,3634 & 0,2404 \\
\hline 13 & Zaporizhzhia & 0,3298 & 0,3193 & 0,3162 \\
\hline 14 & Cherkasy & 0,3292 & 0,3299 & 0,2480 \\
\hline 15 & Khmelnytskyi & 0,3288 & 0,3129 & 0,2388 \\
\hline 16 & Vinnytsia & 0,3114 & 0,2892 & 0,2328 \\
\hline 17 & Dnipropetrovsk & 0,3063 & 0,3368 & 0,2935 \\
\hline 18 & Odesa & 0,3045 & 0,3214 & 0,2884 \\
\hline 19 & Poltava & 0,3045 & 0,2668 & 0,2887 \\
\hline 20 & Kharkiv & 0,2916 & 0,2755 & 0,2495 \\
\hline 21 & Luhansk & 0,2862 & 0,2056 & 0,2261 \\
\hline 22 & Mykolaiv & 0,2699 & 0,2127 & 0,2110 \\
\hline 23 & Kirovohrad & 0,2028 & 0,2027 & 0,2017 \\
\hline 24 & Donetsk & 0,1520 & 0,1121 & 0,1001 \\
\hline & & & \\
\hline
\end{tabular}

Table is made by the author based on: (Koriavets, 2017; Korobov, 2016; Kozachenko, Adamenko, 2015)

The research conducted indicates the insufficient use of the potential of European integration of regions of South-Ukrainian region (Odesa, Kherson, and especially Mykolaiv region), the presence of numerous imbalances in meaningful components of the system process. The most priority are Carpathian regions, regions of the central part of Ukraine have the mean values. 
Among the most important imbalances, there is lack of institutional support for European integration, which negatively influences both the European Integration Index, which is the quintessence and generalization of such a support, as well as the effectiveness by purely economic components. The second imbalance is unevenly distributed financing of economic relations between the regions and the EU, as well as import substitution, especially for goods with high value added. Additional asymmetry of corresponding flows is illustrated by examples of such indicators as: the number of transfers from the EU, the share of accumulated investments of non-residents in the regions, and so on. The analysis conducted only confirms the general conclusions about the state of reforms in the direction of the European integration economic progress of the regions.

The process of Ukraine's integration into the European community continues. Such a process cannot be considered in a specified manner, i.e. only in one plane (economic, political or cultural). It is complex in essence, and its consequences have different nature. Such consequences may be both positive and negative. Using the method of scenario analysis in the most general terms, the consequences of the European integration for the economy of Ukraine in general are presented in Figure 2 (Tarasiuk, 2013; Marmazov, Pilyayev, 2013; Draškovic, Draškovic, 2012).

It is appropriate to investigate the influence of European integration process on the development of Ukraine step by step. At the first stage, one should study how European integration will influence the national economy, its state, and processes that make a significant impact on the economic development of enterprises. To conduct an analysis of the influence of European integration on the economic development of Ukraine, let us use the scenario method that provides an opportunity to identify the most probable scenarios.

At the second stage, it is necessary to consider what threats to economic development each of the scenarios of changes in the economy of Ukraine over the processes of European integration has. Formation of such scenarios is possible (Table 2) (Three scenarios for the development of Ukraine-EU relations after the elections, 2012; Yermolaiev, Parakhonskyj, Yavorska, Reznikova [ta in.], 2012; Elements of the EU strategy for Ukraine (Czech view: Policy statement), 2013).

Names of scenarios to some extent reflect their essence. Certainly, the scenarios provided do not exhaust all possible ones and the given list of scenarios cannot be considered as closed, that is, finally formed. The proposed list of scenarios demonstrates possibilities of determining changes in the economy of Ukraine over the processes of European integration.

Each of the scenarios in Table 2 should receive a qualitative assessment. It is proposed to be given by the following criteria:

- the desirability of scenarios (on a five-point scale, where 1 means an extreme reluctance and threat to the national economy, and 5 is a positive and desirable scenario);

- the probability of implementation of the scenario (on the three-position qualitative scale "high", "average", "low");

- time of implementation of the scenario.

The choice of the latter criterion is determined by the fact that the consequences of European integration are not immediately evident. Thus, it is expedient to

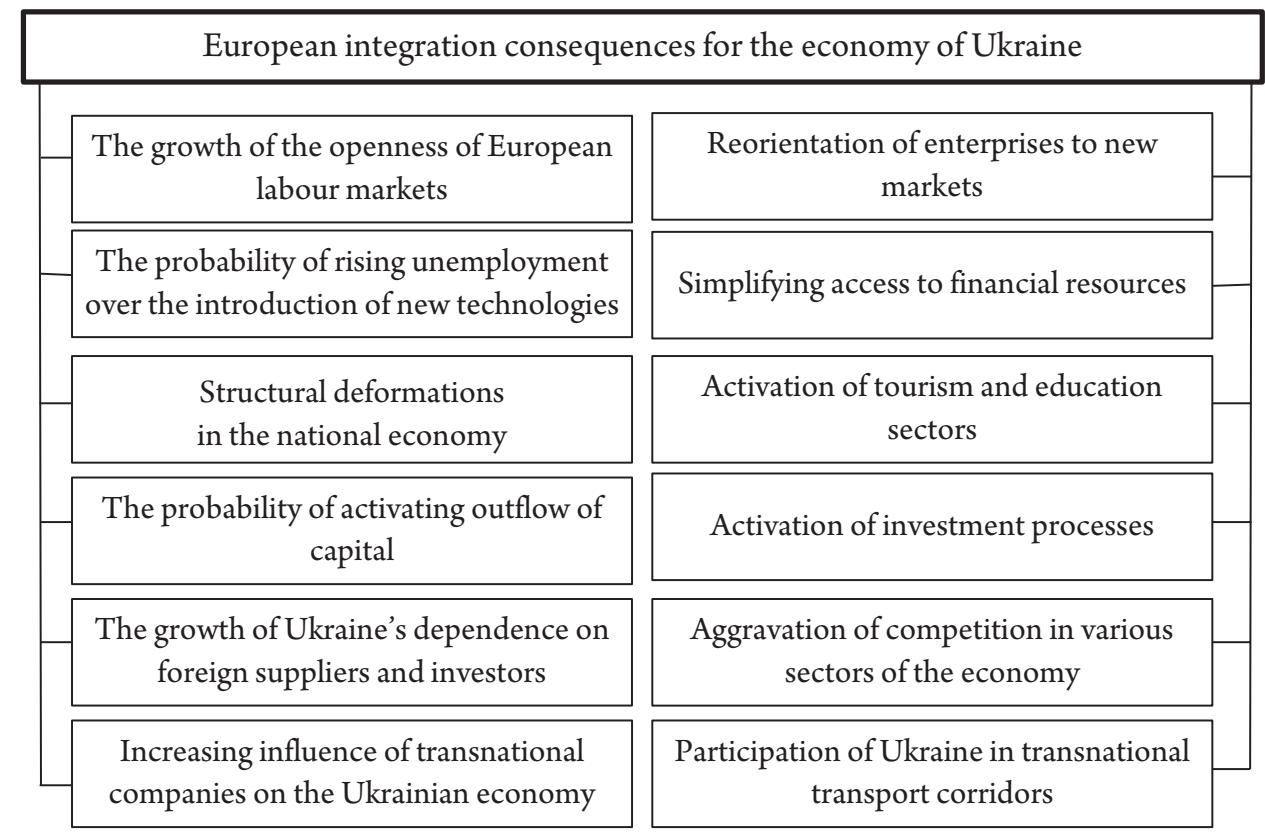

Fig. 2. Determining the consequences of European integration for the Ukrainian economy 
Table 2

Scenarios of Ukraine's economic changes as a result of the influence of European integration processes

\begin{tabular}{|c|c|}
\hline Scenario's name & Brief description \\
\hline $\begin{array}{l}\text { 1. Capture of the national economy } \\
\text { by TNCs }\end{array}$ & $\begin{array}{l}\text { Transnational companies, through mergers and acquisitions, occupy a dominant position in the } \\
\text { Ukrainian economy. The most attractive sectors of the economy go beyond the control of state } \\
\text { administration bodies and move on the basis of the ownership right to TNCs. }\end{array}$ \\
\hline $\begin{array}{l}\text { 2. Development of the national } \\
\text { economy }\end{array}$ & $\begin{array}{l}\text { All segments of the national economy, due to the inflow of investments, new technologies, entering } \\
\text { new markets, are essentially qualitatively and quantitatively growing. National GDP is increasing. }\end{array}$ \\
\hline 3. Investment sea & $\begin{array}{l}\text { Significant volumes of foreign investment have a health impact on the domestic economy, which } \\
\text { allows improving its state at the expense of openness of new markets and access to new resources. }\end{array}$ \\
\hline $\begin{array}{l}\text { 4. Intervention and assignment of } \\
\text { quotas }\end{array}$ & $\begin{array}{l}\text { There is a competitive intervention of foreign producers in the Ukrainian market, which results in a } \\
\text { reduction in the share of national producers. At the same time, the access of Ukrainian producers to } \\
\text { foreign markets is limited to using the quota mechanism. }\end{array}$ \\
\hline 5. Specialization & $\begin{array}{l}\text { Only certain segments and sectors of the national economy, thanks to the international division of } \\
\text { labour and the existing competitive advantages, will be able to develop. In other segments, over the } \\
\text { domination of foreign manufacturers, stagnation will take place. }\end{array}$ \\
\hline 6. Tariff deficit & $\begin{array}{l}\text { The domestic market raises prices for a significant list of goods at the expense of equalization of prices } \\
\text { in the Ukrainian and foreign markets. Products whose prices in foreign markets are higher than prices } \\
\text { in the Ukrainian market are exported, which may lead to a commodity deficit in the national market. }\end{array}$ \\
\hline $\begin{array}{l}\text { 7. Agrarian development of the } \\
\text { national economy }\end{array}$ & $\begin{array}{l}\text { Serious development at the expense of new technologies and openness of the new markets of the } \\
\text { agrarian sector of the Ukrainian economy. Other segments of the national economy are developing } \\
\text { slowly and gradually moving along the path of stagnation. }\end{array}$ \\
\hline 8. Shortage of skilled manpower & $\begin{array}{l}\text { A significant number of qualified specialists, through the simplification of employment abroad, leave } \\
\text { the Ukrainian labour market, which is why domestic enterprises are starting to experience shortages } \\
\text { of skilled personnel. }\end{array}$ \\
\hline 9. No significant change & $\begin{array}{l}\text { Serious changes in the Ukrainian economy due to institutional reasons, despite an access to new } \\
\text { resources and opportunities, will not happen. Cases of a successful exit of domestic enterprises into } \\
\text { foreign markets and successful partnerships with foreign producers will remain rare. }\end{array}$ \\
\hline
\end{tabular}

Compiled by the author

consider two horizon periods - mid-term and long-term. Characteristics of scenarios of changes in the national economy according to the results of the influence of European integration processes are provided in Table 3.

It is evident that scenarios presented in Table 2 cannot be implemented simultaneously. Separation of scenarios according to the criteria "time of implementation of the scenario" and "probability of implementation of the scenario" allows building a scenario map.

An analytical study of the scenarios of changes in the national economy as a result of the influence of the processes of European integration provides the basis for the following conclusions:
- in the mid-term period, only one scenario out of four considered - Investment Sea - will be favourable for domestic enterprises. Other scenarios, although some of them are scarcely probable, will make problems for domestic enterprises, including in providing economic security; - in the long-term period, in spite of positive consequences for the national economy due to European integration, the scenario of Capturing the National Economy with Foreign Transnational Companies is quite likely. Such a scenario for the economic security of enterprises that will not be of interest to transnational companies is threatening; - the scenario of Flowering of the National Economy is possible under thre condition of the previous realization

Table 3

Assessment of scenarios of changes in the Ukrainian economy as a result of the influence of integration processes

\begin{tabular}{|l|c|c|c|}
\hline \multicolumn{1}{|c|}{ Scenario's name } & $\begin{array}{c}\text { Desirability of scenario } \\
\text { implementation }\end{array}$ & $\begin{array}{c}\text { Probability of scenario } \\
\text { implementation }\end{array}$ & $\begin{array}{c}\text { Time of scenario } \\
\text { implementation }\end{array}$ \\
\hline 1. Capture of the national economy by TNCs & 2 & Average & Long-term \\
\hline 2. Flowering of the national economy & 5 & Low & Long-term \\
\hline 3. Investment sea & 4 & Average & Mid-term \\
\hline 4. Intervention and assignment of quotas & 1 & Average & Mid-term \\
\hline 5. Specialization & 3 & Average & Mid-term \\
\hline 6. Commodity shortage & 2 & Low & Long-term \\
\hline 7. Agrarian development of the economy & 2 & Average & Mid-term \\
\hline 8. Shortage of skilled manpower & 1 & Low & Long-term \\
\hline 9. No significant change & 2 & High & \\
\hline
\end{tabular}

Compiled by the author 
of the scenario of Investment Sea, which envisages significant foreign investment inflow in Ukraine. However, foreign investments are always targeted, that is, funds are invested in enterprises, which, according to certain criteria, are selected by foreign investors. If the enterprise does not meet the criteria of foreign investors, then it will not receive these investments, which will negatively affect its economic security.

- other mid-term scenarios do not allow entering the path of sustainable development of the national economy and economic security;

- in the long-term period, there is a significant scenario uncertainty since the relation between scenarios with long-term and mid-term periods of implementation is very close and, at the same time, absolutely uncertain;

- the scenario of the Specialization of the domestic economy as a result of the international division of labour is likely in the whole set of scenarios. A partial kind of such a scenario is the agrarian development of the Ukrainian economy, which will negatively affect the economic security of enterprises by other types of economic activities, which are not related to agriculture directly or indirectly;

- probable is the scenario of the lack of significant changes in the domestic economy regardless of all European integration process of Ukraine. The basics of such a scenario are largely laid down by actions of the government today - lack of real reforms, an effective fight against corruption, and political stability.

The given scenarios of changes in the national economy due to the influence of the processes of European integration may be of interest to the study, it is especially important to consider the issue of influence on the economic security of domestic enterprises.

\section{Conclusions}

The research conducted allowed selecting a toolkit that can be used for evaluating the progress of economic reforms in the context of European integration and identifying the directions of activation of economic security of the country as a whole and individually by regions. In order to calculate the integral index (European Integration Index), it is proposed to use the method of the weighted arithmetic mean. The effectiveness of European integration of the region depends, on the one hand, on the effectiveness of reforms by the direction I: Trade and trade-related issues and, on the other hand, on the effectiveness of reforms by the direction II: Economic and sectoral cooperation. Each of them includes corresponding blocks of indicators reflecting reforms' priority directions. For their description, the statistical indicators, information about which is in open access, were selected.

The promising direction of further research is to conduct a comparative analysis of integrated indexes of European integration of regions, values of their subscripts by the main directions of reforms.
According to the provisions set forth, the following conclusions can be drawn:

- European integration is an objective process, which takes place at the level of the national economy, and individual enterprises cannot significantly affect it;

- European integration as an objective process has a set of consequences for all facets in Ukraine;

- European integration consequences form both opportunities and threats to domestic enterprises;

- overcoming or neutralization of threats to the economic security of domestic enterprises as a result of European integration opens up new opportunities for them, strengthens their positions (including in the markets), and the realization of threats, on the contrary, weakens them;

- European integration processes for the economy of Ukraine can develop according to provided interrelated scenarios that are evaluated according to the proposed criteria;

- consequences of implementation, which can influence the economic security of Ukraine, are determined for each of the presented scenarios of changes to the national economy as a result of the influence of European integration processes.

The practice of the EU-Ukraine cooperation in the field of justice testifies about the inconsistency, delay in government legislative harmonization measures. That is why it is necessary to combine the efforts of the Centre for Democratization of Society (public organization) and the Ministry of Foreign Affairs of Ukraine during the implementation of the project "Assistance to Executive Authorities of Ukraine in the Implementation of the Strategy of Ukraine's Integration into the European Union." Support on the side of the EU provides for two components - the counselling assistance on issues of planning and the transformation of the legal and institutional framework, which is the basis of the civil service, in order to improve activities of government structures, increase their capacity and professional level. It is necessary to reform administrative structures and mechanisms of their activity, determine political responsibility and administrative capacity of authorities to ensure the implementation and enforcement of cooperation agreements with the EU.

We consider that difficulties in the process of adaptation of domestic legal environment to the EU legal framework to a great extent appear due to the extralow level of legal consciousness of society, first of all, its political and economic management that, in its turn, is influenced by the lack of sustainable, organizational, and legally provided concept of legal protection of the population.

Results of the analysis of implementation of each scenario of changes to the national economy as a result of influence of European integration processes are of interest both in the context of determining prospects of the domestic economy when switching from one 
scenario to another, and in the view of providing economic security of domestic enterprises according to the results of identification of fairly actualized scenario.
Further research directions are based on possibilities to develop a strategic map of Ukraine's development scenarios in the context of European integration.

\section{References:}

Avanasova N.E. (2016). Economic security of Ukraine in the system of economic security of the European Union. Bulletin of the Economy of Transport and Industry, 56, 74-82. (in Ukrainian).

Contract - legal cooperation Ukraine - EU (2013). The Delegation of Ukraine to the European Union, the Verkhovna Rada of Ukraine, Committee on European Integration, 27.02.2013. Retrieved from: http://comeuroint.rada.gov.ua/ komevroint $/ \mathrm{control} / \mathrm{uk} / \mathrm{publish} /$ article;jsessionid=653A3AA11F0E0A3ED760591CBC45D1A8?art_id= 55176\&cat_id=47123. (in Ukrainian).

Draškovic, $\bar{V}$., Draškovic, M. (2012). "Institutional Nihilism as a Basis for Anti-Development Policy”, Montenegrin Journal of Economics, Vol. 8, No. 1, pp. 119-136. (in Montenegro).

Derij Zh., Zosymenko T. (2016). Methodology for Assessing the Progress of Economic Reforms: Regional Dimension of European Integration, Problemy i perspektyvy ekonomiky ta upravlinnia [Problems and prospects of economy and management], 2(6), 9-17 (in Ukrainian).

European integration (2011). Moscow: Business literature (in Russian).

Elements of the EU strategy for Ukraine (Czech view: Policy statement) (2013). Institutional Reforms in the EU. Analytical Quarterly, 4, 67-74, (in Ukrainian).

Hluschenko O.O., Tuleninova D.M. (2016). Influence of Eurointegration on the economic security of domestic enterprises. Scientific herald of Mukachevo State University. Series Economics, 195, 112-119 Retrieved from: http://nbuv.gov.ua/ UJRN/nvmdue_2016_1_20_(in Ukrainian).

Honcharenko O.M., Bohatyrenko A.O., Bakal K.V., Vynokurova A.I., Halimuk B.O., Hejderova K.T. (2017) Problems and prospects of European integration of Ukraine. Retrieved from; http://jrnl.nau.edu.ua/index.php/IMV/ article/viewFile/5915/6665 (in Ukrainian).

Ivankiv O.Ya. (2015). The essence of the system of economic security of the enterprise and the conditions of European integration. Scientific Herald of the International Humanitarian University Series: Economics and Management, 11, 109112. (in Ukrainian).

Kaynak, M. (2011). Economic Growth Theories, Gazi Publishing, Ankara. (in Turkey).

Koriavets M. (2017). Index of European Integration Economic Advancement in Ukraine. Report. Chernihiv: Polissya Foundation for International and Regional Studies Retrieved from: http://pfirs.org/produkti/book/59-indeksevrointegratsijnogo-ekonomichnogo-postupu-regioniv-ukrajini/3-produkti.html (in Ukrainian).

Kozachenko H., Adamenko T. (2015). Economic security of an enterprise: an analysis of existing definitions. Scientific Herald Poltava University of Economics and Trade, 1(69), 90-95 (in Ukrainian).

Korobov V.K. (2016). The Index of Eurointegration Economic Progress of the Regions of Ukraine in the Course of Regional Studies. Scientific Bulletin of the Kherson State University. Series geographic sciences, 4, 22-26 (in Ukrainian). Marmazov V., Pilyayev I. (2013) With a road map on the way to the EU. Politics and time, 11, 36-41 (in Ukrainian). Pogorelov Ju. S., Adamenko T. (2015). Problems of forming a methodological basis of the science of economic security of the enterprise. New Economy, 2(66), 173-181 (in Russian).

Association Agreements between Ukraine and the EU to prepare and facilitate the implementation of the Association Agreement dated March 16, 2015. [Web-portal of Ukrainian Government]. Retrieved from http://www.kmu.gov.ua/kmu/control/en/publish/article?art_id=248542569\&cat_id=248542039.

Pryimak, V.I. (2009). Mathematical methods of economic analysis. Kyiv: Tsentr uchbovoi literatury (in Ukrainian). Tarasiuk, B. (2013). Ukraine-EU: Priorities, Problems, Prospects. EU-Ukraine Cooperation: Analytical Quarterly, 3, 19-26. (in Ukrainian).

Three scenarios for the development of Ukraine-EU relations after the elections (2012). Retrieved from: http://iwp.org.ua/img/tri_czenari_ukr.pdf. (in Ukrainian).

The Association Agenda between Ukraine and the EU to prepare and facilitate the implementation of the Association Agreement of 16.03.2015. Retrieved from: http://www.kmu.gov.ua/control/uk/publish/article\%3fshowHidden= 1 \&art_id=243281941 \&cat_id=223 345338\&ctime $=1266423569791$. (in Ukrainian).

Association Agreement between the European Union its Member States, of the one part, and Ukraine, of the other part 27.06.2014]. Official web portal of Verkhovna Rada Ukraine. Retrieved from http://zakon4.rada.gov.ua/ laws/show/984_011/paran2820\#n2820. (in Ukrainian).

Venice Commission to publish conclusions on changes to the Constitution in the part of the system of judicial system in June 921.05.2013) Retrieved from: http://www.ukrinform.ua/ukr/news/venetsianska komisiya oprilyudnit_ visnovki_shchodo_zmin_do_konstitutsiii_v_chastini sistemi_sudoustroyu_u_chervni_1 $\overline{82875}$ (in Ükrainian). Yliashenk $\bar{k}$ E. V. (2015). Economic security of the enterprise: the content of the concept. L'AssocTatTon $1901 \ll S E P I K E »$, 11, 162-168 (in Ukrainian).

Yermolaiev A.V., Parakhonskyj B.O., Yavorska H.M., Reznikova O.O. [ta in.](2012). European project and Ukraine: monograph. Kiev. : NISD, 111-117. (in Ukrainian).

Zubok M. I. (2012). Economic security of entrepreneurs: a manual, Kiev:Beam (in Ukrainian). 